\title{
Fractal Properties of the Financial Market ${ }^{\#}$
}

\section{Lukáš Vácha*}

\section{Introduction}

Modern finance experiences an important change in perceiving an economic agent. A representative rational agent approach is substituted with a behavioral one. Agentbased approach in which markets represented by boundedly rational, the heterogeneous agents are using rule of thumb strategies.

The new behavioral approach fits much better with agent-based simulation models and computational and numerical methods have become an important tool of analysis (Hommes, 2006). The new behavioral, heterogeneous agents approach challenges the traditional representative, rational agent framework. Heterogeneity in expectations can lead to market instability and complicated dynamics of prices. In the heterogeneous agents models (HAMs) prices are driven by endogenous market forces. Typically the (HAM) consists of two types of agents; fundamentalists and chartists. Fundamentalists base their expectations about future asset prices and their trading strategies upon market fundamentals and economic factors, such as dividends, earnings, macroeconomic growth, unemployment rates, etc. Chartists or technical analysts try to extrapolate observed price patterns, such as trends, and exploit these patterns in their investment decisions.

In my joint work with M. Vošvrda, from the beginning we started to focus on a simple HAM with two or four types of beliefs (Vošvrda, Vácha, 2002). These beliefs were fixed for all our simulations. In our subsequent papers (Vošvrda, Vácha, 2002a, $2002 \mathrm{~b}, 2003)$, we employed a memory and some learning schemes in the Brock and Hommes's model $(1997,1998)$. Then we used the core of the Brock and Hommes's model on which we base further extensions, such as a stochastic formation of beliefs and parameters including a memory length. Another extension is in an application of the worst out algorithm (WOA). In (Vácha, Vošvrda, 2005) we show how a memory length distribution in the agents' performance measure affects a persistence of the generated price time series. In paper (Vácha, Vošvrda, 2007) we demonstrate a rising trend as the replacement ratio of the WOA increases. We also observe higher returns time series volatility as the replacement ratio rise.

My motivation is to deepen the behavioral aspects of the HAM. An investigation of connections of this aspect in HAM is now realized by an influence of the mood change and examination of this qualitative change on the financial market structure. This feature is simulated by changing the mean of trend $g$ for the new strategies that enter the market via the WOA.

A support from the Czech Science Foundation under the grant 402/03/H057 and 402/06/1417 is gratefully acknowledged.

Mgr. Lukáš Vácha - research fellow; Institute of Economic Studies, Faculty of Social Sciences, Charles University in Prague, Smetanovo nábřeží 6, 11101 Prague 1, Czech Republic, <vachal@utia.cas.cz>. 


\section{Model and the WOA}

The core of the model that is used in this paper is an asset-pricing model with one risky asset and one risk-free asset. The beliefs (or trading strategies) and other parameters including a memory length (equivalent of investment horizons) are stochastically formed. The model also uses last generation of the WOA (see Vácha and Vošvrda 2007). There is a possibility to change investors' mood. This new version allows changing phases of optimism and pessimism on the market, this new feature helps to make the model more realistic.

The model considers the financial markets as systems of the interacting agents processing new information immediately. Prices are driven by endogenous market forces. Agents adapt their predictions by choosing among a finite number of predictors. Each predictor has a performance measure. Based on this performance measure, agents realize a rational choice among the predictors (for more detail treatment of this basic attributes see Brock - Hommes, 1998). This approach relies on heterogeneity in the agent information and subsequent decisions either as fundamentalists or as chartists, see also (Chiarella, 1992; Chiarella - He, 2000).

The model is described in detail in Vácha and Vošvrda 2007. I would like to depict here only the very important parts. The measure of profits is generated by forecasts $f_{h, t}^{\mathbf{L}}$, see Equation 4 . Let a performance measure $\pi_{h, t}$ be defined by

$$
\pi_{h, t}=E_{t}\left[\frac{\mathbf{Z}_{t+1} \cdot \rho_{h, t}}{a \cdot \sigma_{t}^{2}}\right],
$$

where $Z_{\mathrm{t}+1}-$ the realized excess return over period $t$ to the period $t+1$,

$\rho_{h, t}-$ the expected value of $Z_{\mathrm{t}+1}$ at time $t$,

a - a risk aversion,

$\sigma_{t} \quad-$ the conditional variance of excess returns that is a constant for all investors types.

The $\pi$-performance is given by the realized performance of the $h$-investor. Let the updated fractions $n_{h, t}$ be given by the discrete choice probability (Gibb's distribution)

$$
n_{h, t}=\exp \left(\beta \cdot \pi_{h, t-1}\right) / Y_{t-1}
$$

where

$$
Y_{t}=\sum_{j=1}^{H} \exp \left(\beta \cdot \pi_{j, t}\right) .
$$

The parameter $\beta$ is an intensity of choice. The parameter $\beta$ is a measure of investor's rationality. If the intensity of choice is infinite $(\beta=+\infty)$, the entire mass of investors uses the strategy that has the highest performance. If the intensity of choice is zero, the mass of investors distributes itself evenly across the set of available strategies. All forecasts $E_{h, t}\left[\mathbf{Z}_{t+1}\right]$ have the following form 


$$
\begin{aligned}
& \rho_{h, t}=E_{h, t}\left[\mathbf{Z}_{t+1}\right]=f_{h}^{\mathbf{L}}\left(x_{t-1}, \ldots, x_{t-\mathbf{L}}\right), \\
& f_{h}^{\mathbf{L}}\left(x_{t-1}, \ldots, x_{t-\mathbf{L}}\right)=g \cdot\left(x_{t-1}+\ldots+x_{t-\mathbf{L}}\right)+b .
\end{aligned}
$$

where $x_{t}$ is the deviation from the fundamental value, $L$ is the memory length. The $g$ denotes the trend of investor forecasts and the $b$ denotes the bias of investor forecasts. If $b=0$, the investor is called a pure trend chaser if $g>0$ and a contrarian if $g<0$. If $g=$ 0 , investor is called purely biased. Investor is upward (downward) biased if $b>0(b<$ 0 ). In the special case $g=b=0$, the investor is called fundamentalist, i.e., the investor believes that price return to their fundamental value. Fundamentalist's strategy is based on all past prices and dividends in their information set, but they do not know the fractions $n_{h, t}$ of the other belief types.

The WOA replaces periodically the trading strategies that have the lowest performance level of strategies presented on the market by the new ones. The algorithm after every 40 iterations evaluates and arranges in descending order the performance of fifteen strategies in the market and the last one or more replaces by the new ones. The new strategies that enter on the market are taken from the set that has the same stochastic parameters as the initial strategies.

\section{Simulations}

Simulations are performed with fifteen agents represented by trading strategies. We use $4 \mathrm{WOA}$, i.e., we replace four strategies, so the replacement ration is $27 \%$, which may seem as a quite high value, but it serves good the simulation of the mood changes. The trend $g$ is generated by a normal distribution with the mean is equal 0 , and variance is equal $0.16(g \sim N(0,0.16))$. The bias $b$ is generated by a normal distribution with the mean is equal 0 , and variance is equal $0.09(b \sim N(0,0.09))$. The memory length $L$ is generated by a uniform distribution on a range of integers $1,2, \ldots, 100(L \sim U(1,100))$, this parameter ensure the equality of the investors' investment horizons lengths. The intensity of choice, $\beta$, is set to 40 . The WOA makes the replacement after 40 iterations, so we have 250 replacements.

\section{Change of Mood on the market}

The first case in the paper, where the trend $g$ is generated by a normal distribution with the mean is equal 0 , and variance is equal 0.16 for the full realization of the simulation, is called the no mood change case. The second case, i.e., the mood change case, examines consequences of the mood change, specifically how the persistence of the generated time series is influenced. In the mood change case the expected value of $g$ is changed. For the first 2000 iterations the trend $g$, of newly incoming strategies on the financial market, is generated from the distribution $N(0,0.16)$. Next for the interval 2000-4000 iterations the trend $g$ is generated from the distribution $N(+0.1,0.16)$. Another 2000 steps (the interval 4000-6000) the trend $g$ is generated from the distribution $N(-0.1,0.16)$. For the interval $6000-8000$ the trend $g$ is generated from the distribution $N(+0.1,0.16)$, and finally for the interval 8000-10000 the trend $g$ is 
generated from the distribution $N(0,0.16)$. This procedure defines a mood structure on the financial market.

\section{The R/S Statistic}

For estimating and analyzing the phenomenon of long memory on financial markets, a nonparametric approach is used. H. E. Hurst discovered very robust nonparametric methodology, which is called rescaled range, or R/S analysis that is used for estimating the Hurst exponent. The R/S analysis was used for distinguishing random and non-random systems, the persistence of trends, and duration of cycles (Peters, 1994). This method is very convenient for an identification of fractal time series. A nice property of the $\mathrm{R} / \mathrm{S}$ statistic is that its asymptotic behavior remains unaffected by longtailed marginal distributions (for a more detailed treatment see Beran (1994).

Starting point for the Hurst's coefficient was the Brownian motion as a primary model for random walk processes. If a system of random variables is an independent identically distributed then the Hurst exponent $\mathrm{H}=0.5$. The values of Hurst exponent, belonging to $0<\mathrm{H}<0.5$, signify an anti-persistent system. Such a system must reverse itself more frequently than a random process can represent. This behavior is very close to a mean-reverting process. The values of Hurst exponent belonging to $0.5<\mathrm{H}<1$, signify a persistent process that is characterized by long memory effects. The long memory occurs regardless of time scale, i.e., there is no characteristic time scale, which is the key characteristic of fractal time series (Peters, 1994), (Los, 2003).

For computation of the $\mathrm{R} / \mathrm{S}$ coefficients we have to divide the time series of length $T$, into $N$ intervals of the length $n$, where $n \cdot N=T$. Values $\left\{(R / S)_{n}\right\}$ are defined in the following form

$$
(R / S)_{n}=\frac{1}{N} \sum_{N} \frac{R_{n}}{S_{n}},
$$

where

$$
R_{n}=\max _{1 \leq k \leq n}\left[\sum_{i=1}^{k}\left(x_{i}-\bar{x}_{n}\right)\right]-\min _{1 \leq k \leq n}\left[\sum_{i=1}^{k}\left(x_{i}-\bar{x}_{n}\right)\right]
$$

is the range and

$$
S_{n}=\sqrt{\frac{1}{n} \sum_{i=1}^{n}\left(x_{i}-\bar{x}_{n}\right)^{2}}
$$

is the sample standard deviation. The Hurst exponent $H$ can be approximated by the following equation

$$
\log \left((R / S)_{n}\right)=\log (c)+H \log (n)
$$

where $c$ is a constant. 
Table 1: Values of the Hurst exponent

\begin{tabular}{ccc}
\hline Interval for the Hurst exp. & H. exp. for Mood change & H. e. for No Mood change \\
\hline $\mathbf{0 - 1 0 K}$ & $\mathbf{0 . 6 2 0}$ & $\mathbf{0 . 6 5 6}$ \\
\hline $0-2 \mathrm{~K}$ & 0.698 & 0.794 \\
\hline $2-4 \mathrm{~K}$ & 0.719 & 0.783 \\
\hline $4-6 \mathrm{~K}$ & 0.676 & 0.748 \\
\hline $6-8 \mathrm{~K}$ & 0.619 & 0.799 \\
\hline $8-10 \mathrm{~K}$ & 0.547 & 0.744 \\
\hline
\end{tabular}

Values of the Hurst exponent for both the cases; with the change of the mood on the market and the case without mood changes are in table 1 and the descriptive statistic of returns are in table 2. In the first row we have the value of the Hurst exponent for the whole interval (all 10000 iterations). Next rows give us values of the intervals during simulation. In general we can say that the case with a mood change has lower Hurst exponent and is closer to a real market data. Higher Hurst exponent for the no mood change case is a consequence of a learning mechanism on the market even though this one is disturbed by the WOA. It is clear that the WOA has, in terms of market efficiency, lower impact than the change of the mood or beliefs of investors (changes in trend $g$ ).

Figure 1: Hurst exponent for the intervals of simulation, each interval has 2000 iterations

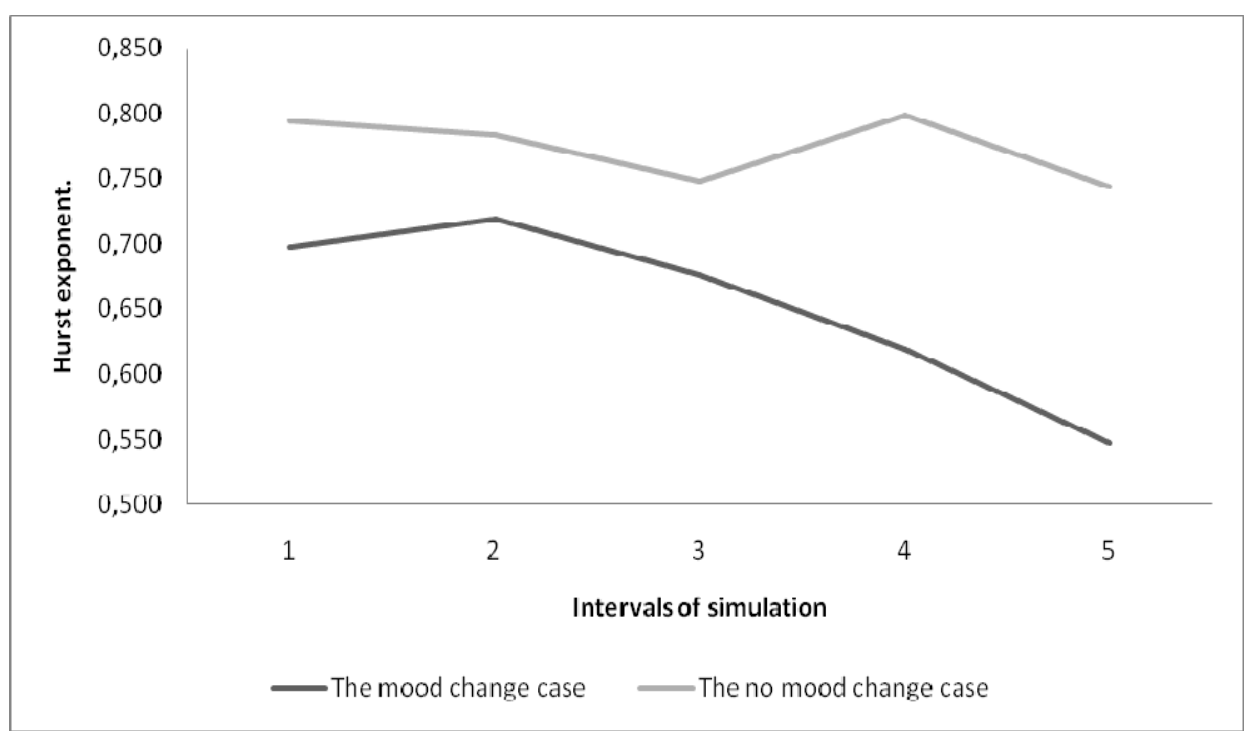

Table 2: Values of the Hurst exponent

\begin{tabular}{ccc}
\hline Descriptive stat. & The Mood change case & No Mood change case \\
\hline Mean & 0.032 & 0.011 \\
\hline Variance & 0.059 & 0.0009 \\
\hline Kurtosis & 3.584 & 1.081 \\
\hline Skewness & 0.945 & 0.875 \\
\hline
\end{tabular}




\section{Conclusion}

An application of the mood change on the financial market brings us new possibility of incorporating the behavioristic approach to the theoretical model. Higher Hurst exponent for the no mood change case is a consequence of a learning mechanism on the market even though this one is disturbed by the WOA. It is shown that the WOA has, in terms of market efficiency, lower impact than the change of the mood or beliefs of investors.

\section{References}

[1] BERAN, J. (1994). Statistics for Long - Memory Processes. New York : Chapman and Hall, 1994.

[2] BROCK, W. A.; HOMMES, C. H. (1997). A Rational Route to Randomness. Econometrica, 1997, vol. 65, no. 5, pp. 1059-1095.

[3] BROCK, W. A.; HOMMES, C. H. (1998). Heterogeneous Beliefs and Routes to Chaos in a Simple Asset Pricing Model. Journal of Economic Dynamics and Control, 1998, vol. 22, no. 8-9, pp. 1235-1274.

[4] BROCK, W. A.; DECHERT, W. D. (2001). Growth Theory, Nonlinear Dynamics and Economic Modeling. Cheltenham : Edward Elgar, 2001.

[5] CHIARELlA, C. (1992). The Dynamics of Speculative Behaviour. Annals of Operational Research, 1992, vol. 37, no. 1-4, pp. 101-123.

[6] CHIARELLA, C.; He, X. (2000). Heterogeneous Beliefs, Risk and Learning in a Simple Asset Pricing Model with a Market Maker. Research Paper no. 35, Sydney : Quantitative Finance Research Group University of Technology Sydney, 2000.

[7] HOMMES, C. H. (2006). Heterogeneous Agent Models in Economics and Finance. In Tesfatsion, L.; Judd, K. L. (eds.). Handbook of Computational Economics. Volume 2: Agent-Based Computational Economics. Amsterdam : North Holland, pp. 1109-1186.

[8] LOS, C. A. (2003). Financial Market Risk: Measurement and Analysis. London : Routledge, 2003.

[9] LUX, T. (1997). Economics Dynamics. Phase Diagrams and their Economic Application. Cambridge : Cambridge University Press, 1977.

[10] VÁCHA. L.; VOŠVRDA, M. (2007). Wavelet Decomposition of the Financial Market. Prague Economic Papers, 2007, vol. 16, no. 1, pp. 38-54.

[11] VÁCHA. L.; VOŠVRDA, M. (2005). Dynamical Agents' Strategies and the Fractal Market Hypothesis. Prague Economic Papers, 2005, vol. 14, no. 2, pp. 172-179.

[12] VOŠVRDA, M.; VÁCHA, L. (2002a). Heterogeneous Agent Model with Memory and Asset Price Behaviour. In Ramik, J. (ed.). Proceedings of the $20^{\text {th }}$ International Conference Mathematical Methods in Economics 2002. Ostrava : VŠB-TU Ostrava, 2002, pp. 273-282. 
[13] VOŠVRDA, M.; VÁCHA, L. (2002b). Heterogeneous Agent Model and Numerical Analysis of Learning. Bulletin of the Czech Econometric Society, 2002, vol. 9, no.17, pp. 15-22.

[14] VOŠVRDA, M.; VÁCHA, L. (2003). Heterogeneous Agent Model with Memory and Asset Price Behaviour, Prague Economic Papers, 2003, vol. 12, no. 2, pp. $155-168$.

\title{
Fraktální vlastnosti finančních trhů
}

\section{Lukáš Vácha}

\begin{abstract}
Abstrakt
Článek se zabývá implementací a dopady behaviorálního př́stupu v modelu s heterogenními agenty za použití tzv. worst out algoritmu (WOA). Tento algoritmus nahrazuje strategie s nízkou výkonností strategiemi novými. Prezentovaný model s heterogenními agenty zahrnuje možnost měnit náladu investorů na finančním trhu. Této vlastnosti je využíváno pro generování simulací. V článku je ukázáno jak změny nálady na finančním trhu ovlivňují perzistenci generované cenové časové řady.
\end{abstract}

Klíčová slova: strategie agentů na finančním trhu; model s heterogenními agenty; změna nálady ne finančním trhu.

\section{Fractal Properties of the Financial Market}

\begin{abstract}
The paper is concerned with an implementation of behavioral aspects of a heterogeneous agents model (HAM) with the worst out algorithm (WOA). The WOA replaces periodically the trading strategies that have the lowest performance level of all strategies presented on the market by the new ones. The model includes a possibility to change the mood of the investors on the market. This modification allows for changing phases of optimism and pessimism. This feature enables generation of more realistic financial time series. It is shown how a mood change on the financial market influence a persistence of financial time series.
\end{abstract}

Key words: agents' trading strategies; heterogeneous agents model with stochastic memory, worst out algorithm; mood change.

JEL classification: C61, G12, G14, D81. 